\section{ECONOMICS}

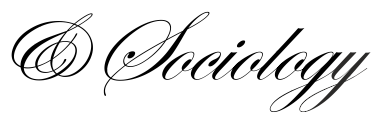

\title{
IMMIGRANTS' CONTRIBUTION AND SHARE: MULTILEVEL ANALYSIS OF MIGRANT LABOUR CONTRIBUTION TO PRODUCTIVITY, WELFARE AND INCOME IN FINLAND
}

\begin{abstract}
Oxana Krutova, University of Tampere, Finland E-mail:oxana.krutova@tuni.fi
\end{abstract}

Received: January, 2019

1st Revision: May, 2019

Accepted: November, 2019

DOI: $10.14254 / 2071-$

789X.2019/12-4/1
JEL Classification: J31, J15, $\mathrm{O} 15$

\begin{abstract}
In this paper we investigate how economic growth and productivity, when adjusted for the influence of welfare state institutions, affects the redistribution of incomes for employed immigrants and natives in Finland. We used the European Union Statistics on Income and Living Conditions (EU-SILC) cross-sectional data for the period from 2004 to 2016 selected for Finland. Based on multilevel modelling and an aggregate production function approach, we calculate the elasticity estimates for incomes as adjusted for the influence of education, occupation and industry and social benefits. The results indicate high differentiation of incomes between immigrants and natives, while showing lower incomes for immigrants. Social benefits slightly decrease incomes, while for immigrants this negative effect is even more pronounced than it is for natives. Economic growth and increase in productivity is associated with an increase in the incomes of both immigrants and natives with low and medium education and of clerical and manual labour occupations among immigrants. Despite the widespread perception that 'immigrant hordes' have an adverse effect on the employment opportunities of natives and their incomes, the research concludes that welfare state benefits in combination with the influence from macroeconomic regulators and productivity increase incomes for immigrants.
\end{abstract}

Keywords: immigrant labour, income redistribution, aggregate production function approach, multilevel modelling, economic performance

\section{Introduction}

Performance of immigrants in a host country's economy and their impact on employment opportunities and incomes of natives are rather disputable topics in scientific literature. The pioneering study of Chiswick (1978) on the earnings of immigrant men led to a renewed interest in the topic of immigrant adjustment within the field of economics. Chiswick (1978) found that immigrant men earned as much as natives despite having less education and 
concluded that investments in on-the-job training made up for the gap in formal education. Later research has shown that immigrants' earnings still remain lower than those of natives even after many years of living in a country (Barth, Bernt \& Raaum, 2004; Barth, Bernt \& Raaum, 2006; Gustafsson \& Zheng, 2006; Villarreal \& Tamborini, 2018; Bijwaard \& Wahba, 2019).

The topic of immigrants' economic performance has come under extensive reexamination in literature. On the one hand, Felbermayra, Hiller and Sala (2010), Ottaviano and Peri (2012) and Ortega and Peri (2014), when controlling for institutional quality, trade, and financial openness, established a robust and positive causal effect of immigration on real income per capite. Immigration increases the value of aggregate output due to a country's openness to trade, measured by policies (Rodrik et al., 2004) or by trade flows as a share of GDP (Noguer \& Siscart, 2005). According to numerous findings, immigration inflows have a positive effect on total factor productivity (TFP) due to increased diversity in productive skills of the work force and higher rate of innovation in production technologies. The policy significance of the issue of immigrants' economic performance in a country is obvious, because immigrants with high levels of productivity make a significant contribution to economic growth in a host country.

On the other hand, economic underperformance of immigrants with low level of adaptation to a local labour market may increase the costs of welfare state programs associated with income maintenance. Borjas and Trejo (1991), Baker and Benjamin (1995), Borjas and Hilton (1996) and Hansen and Lofstrom (2003) found an increase in welfare participation rates across successive immigrant waves and also found that immigrants use welfare to a greater extent than natives. According to other studies, economic performance of immigrants is rather controversial in terms of increasing poverty and income polarization (Galloway \& Aaberge, 2005; Blume et al., 2007). Job polarization turns out to be one of the basic explanations for wage redistribution and poverty in Finland (Asplund et al., 2011; Goos, Manning \& Salomons, 2009; Mitrunen, 2013).

When treating immigration as incoming labour supply, the aggregate production function approach aims to identify allocative efficiency in the use of production factors (e.g., immigrant labour versus native labour) and the redistribution of income due to those factors. When supposing that one factor may be imperfectly substituted for another (e.g., immigrant versus native labour), the impact of immigration may potentially produce improved factor contribution efficiency. In this article, we investigate how economic growth and productivity, when adjusted for the influence of welfare state institutions, affect the redistribution of incomes among employed immigrants and employed natives. This study used the aggregate production function as a structural foundation to employee cash income regressions.

We therefore propose to answer the following two research questions:

1) Supposing that one input factor in production (e.g., native labour force) is substituted by another factor input (e.g., immigrant labour force), how does income redistribution change due to the influence of economic growth, productivity and welfare state provision?

2) How do selection and compositional effects (education, occupation and industry) affect changes in income redistribution due to the influence of economic growth, productivity and welfare state provision?

This article is organized as follows. Section 2 provides theoretical reflections on the studies used to estimate the impact of immigration on the income redistribution of natives. Section 3 describes the data set, variables, and the statistical method used. Section 4 provides descriptive evidence and the results of multilevel analysis. Section 5 discusses the results and reaches theoretical and political conclusions. Finally, Sections 6 and 7 are bibliography and appendix accordingly. 


\section{Literature review}

\subsection{Selection and compositional effects in the redistribution of incomes}

In the literature there is a clear evidence supporting arguments that immigrants have difficulties in entering and remaining in the labour market, however, the analysis is often restricted only to those who are in employment and the results may therefore entail a selection bias. To overcome methodological shortcomings of this kind, Hammarstedt (2003) makes a good exception by taking into account the selection effect when explaining the probability of having an income from employment and gives room for other explanatory variables (e.g., education) as well. Continuing this research line, Galloway (2008) explains differences in incomes from employment between immigrants and natives due to education, experience, civil status, region of residence or from being a member of a cohort.

On the other hand, the compositional effect of immigration and its effects on income distribution is important in case the skill composition of immigrants does not match the skill composition of natives. For example, Blau ja Kahn (2012) found that a change in skill composition leads to disequilibrium between the supply and the cost-minimizing demand for different labour types at existing wages. As a result, foreigners may potentially induce declining wages and rising unemployment as in the case of natives and immigrants being imperfect substitutes (Borjas, 1987; Card \& Lemieux, 2001; Ottaviano \& Peri, 2012; Manacorda, Manning \& Wadsworth, 2012; Clarke, Ferrer \& Skuterud, 2019). As Mishchuk et al. (2019) have found, intellectual migration can cause significant destructive consequences for national competitiveness.

In the light of a labour market equilibrium framework, when the impact of immigration is considered within a structural model of production combining workers of different skills with capital, the effect of immigration on the wages of native workers of different skills in the long term is expected to differ (Borjas, 2003; Aydemir \& Borjas, 2007, 2011; Manacorda, Manning \& Wadsworth, 2012; Ottaviano \& Peri, 2008; D’Amuri, Ottaviano \& Peri, 2010; Lewis, 2003). In this respect, the effect of immigration upon income redistribution turns out to be as direct (which refers to the change in wages taking place for given employment levels of natives and immigrants) as it is indirect (which refers to the change in wages due to changes in those employment levels).

\subsection{Aggregate production function approach to the education-specific labour markets}

In the frame of the aggregate production function approach, recent research produced three scenarios according to which immigration differently affects income redistribution between immigrants and natives. In the frame of the first scenario, immigration potentially increases the wages of natives or does not affect wages at all. For example, Card (2009), Ottaviano and Peri (2012) and Dustmann, Frattini and Preston (2013) concluded that immigration had a small positive effect on the wages of native workers with no high school degree. Finally, Card (1990), LaLonde and Topel (1991), Card (2005), Dustmann, Fabbri and Preson (2005) and Cortés (2008) concluded that immigrants did not affect the wages of natives and in addition, low-skilled immigrants did not affect native wages or the unemployment of unskilled workers.

In the frame of the second scenario, immigration potentially decreases wages of the native population. For example, Altonji and Card (1991), Borjas, Freeman and Katz (1997), Borjas (2003), Bonin (2005), Aydemir and Borjas (2007), D'Amuri, Ottaviano and Peri (2010), Cohen-Goldner and Paserman (2011) and Manacorda, Manning and Wadsworth (2012) found 
that the redistributive effects of immigration had adverse effects on native wages and on their employment levels, as well as the finding that immigrant influx reduced the wages of the average native worker and this wage impact differed dramatically across low-skilled education groups and unskilled workers.

In the frame of the third scenario, immigration reduces the wages of those immigrants who moved to the country before the cohort under study. For example, Cortés (2008), D'Amuri, Ottaviano and Peri (2010) and Ottaviano and Peri (2012) and Manacorda, Manning and Wadsworth (2012) found that new immigration had a negative impact on the employment of less skilled immigrants who entered the county before the new arrivals, driven by wage rigidities, suggesting closer competition between new and old immigrants than between immigrants and natives, as well as differences in the insider-outsider status of natives and immigrants.

\subsection{Aggregate production function approach to the occupation-specific labour markets}

Assuming that local labour markets are occupation specific, a distinction is drawn between different occupational groups. In such a model the effect of immigration depends on the substitutability between immigrant and native labour of different skill levels. Earlier papers distinguished between effects on skilled and unskilled workers (Altonji \& Card, 1991; Card, 2001; Borjas, 2003; Dustmann, Fabbri \& Preston, 2005) or analysed the effect of immigration on relative wages with regard to specific skill groups (Card, 2005; Card \& Lewis, 2011; Manacorda, Manning \& Wadsworth, 2012; Ottaviano \& Peri, 2008; Ottaviano \& Peri, 2012).

According to the findings of previous research, the overall impact of immigration on native labour depends on between-group differentials and within-group inequality. For example, Winter-Ebmer and Zweimüller (1996) found that increased immigration had a positive effect on the wages of young native blue collar workers. However, Card (2001) and Borjas and Friedberg (2009) found that inflows of new immigrants reduced the relative employment rates of natives and earlier immigrants in physical work and low-skilled service occupations. Friedberg (2001) found that an increase in occupational employment due to immigration was associated with a decrease in the real hourly earnings of natives in that occupation. Natives also react to the arrival of large immigrant groups with interregional outmigration toward occupations less exposed to immigration (Amuedo-Dorantes \& De la Rica, 2011; Martins, Piracha, \& Varejão, 2018).

\subsection{Aggregate production function approach to industry-specific labour markets}

With regard to aggregate production function and competition in industry specific labour markets, Card (2005) found that immigration had a strong effect on the relative supply of different skill groups, but local industry structured their responses to immigration-induced supply shocks (e.g., the absorption of unskilled immigrants) within the industries of highimmigrant cities, rather than between industries. This raises the question of how firms in a given industry can so closely adapt their production technology to local supplies of different types of labour without substantial changes in relative wages.

A firm bargaining model beyond labour supply effects explains one part of the phenomena when arguing that a high share of foreign workers within the firm may reduce the bargaining power of natives and in turn, hamper wage concessions reached in negotiations with management. According to the other hypothesis, a high share of immigrants in a specific firm might be considered beneficial to natives, if natives are able to exploit the foreigners in a twotier wage system. Winter-Ebmer and Zweimüller (1996) confirm a preponderance of the second 
hypothesis; no negative wage effects of high immigrant shares have been found either on a regional or an industry level, because wage premiums for natives are potentially necessary to compensate for collaboration with foreign workers.

However on the other hand, an increase in the share of low-skilled immigrants in the labour force decreases the price of immigrant-intensive services, such as housekeeping and gardening (Cortés, 2008). It may also happen that low-skilled immigration lowers skill intensity and wages in construction, hotels and restaurants and domestic services (industries which produce non-traded goods) without affecting less-skilled native workers' relative wages (González \& Ortega, 2011). If the degree of substitution between capital and the different skill groups differs, it may be possible to build an alternative explanation for the evidence found in above-mentioned research. One of the potential explanations for these conclusions is that natives and immigrants are imperfect substitutes in production even when controlling for education and occupation (Peri \& Sparber, 2009).

\section{Methodological approach}

\subsection{Data}

We conducted the statistical processing of the European Union Statistics on Income and Living Conditions (EU-SILC) cross-sectional data using R 3.5.1. EU-SILC is the EU reference source for comparative statistics on income distribution and social exclusion at the European level. Cross-sectional data pertained to a given time or a certain time period with variables on income, poverty, social exclusion and other living conditions. The multilevel modelling was based on two-step individual-level analysis with the usage of micro-data from the EU-SILC for Finland for the period of 2004 to 2016, which contains a sample of 2,484 cases for immigrants and 107,501 cases for natives. The sample is based on nationally representative probability samples of the population residing in private households within the country. In addition, the statistical model has been adjusted for weight coefficients, with estimations as required to take into account the units' probability of selection, non-response and as appropriate, to adjust the sample to external data relating to the distribution of individuals in the target population, such as by household size and composition, sex, age, and region, or relating to income data.

We surmised the random effects (cash incomes) and fixed effects (education, occupation, industry, welfare state benefits) at the micro-level and macro-economic indicators at the macro-level: gross domestic product (GDP), gross national income (GNI), value added, labour productivity (LP), total-factor productivity (TFP), contribution of total capital input, ICT- capital input, R\&D, machinery and equipment, worked hours on TFP, contribution of capital intensity, ICT-capital intensity, R\&D intensity and equipment and machinery capital intensity on LP.

\subsection{Micro-level variables}

Our basic is "Employee cash or near cash income", which includes income/gross personal income, total and components at personal level during the income reference period (yearly) in Euros (Table 1 in Appendix). Gross income means that neither taxes nor social contributions have been deducted at source. Employee income is defined as the total remuneration, in cash or in kind, payable by an employer to an employee in return for work done by the latter during the income reference period.

Social benefits are defined as current transfers received by households during the income reference period, which are intended to relieve them from the financial burden of a 
number of risks or needs. Estimates are also given in Euros. Social benefits include the value of any social contributions and income tax payable on the benefits by the beneficiary to social insurance schemes or to tax authorities. The Social benefits collected at the individual level are the following: 'Unemployment benefits', 'Old-age benefits', 'Survivor' benefits', 'Sickness benefits', 'Disability benefits' and 'Education-related allowances'.

The following variables were also considered (Table 2 in Appendix). The 'education' variable includes two categories of education: 'low (lower secondary) and medium (upper secondary)' and 'high (tertiary level)'. This dummy variable is considered in the model as a factor variable including two dimensions, including the reference group: 'higher education'. The next variable 'occupation' is based on ISCO-classifications and includes nine groups: 'Legislators, senior officials and managers', 'Professionals', 'Technicians and associate professionals', 'Clerks', 'Service workers and shop and market sales workers', 'Skilled agricultural and fishery workers', 'Craft and related trades workers', 'Plant and machine operators and assemblers', 'Elementary occupations'. This variable is considered in the model as a factor variable including nine dimensions, including the reference group: 'Legislators, senior officials and managers'. The last variable 'industry' is based on NICE-classifications and includes twelve groups: 'Financial intermediation (ref. group)', 'Agriculture, hunting and forestry, fishing', 'Mining and quarrying, manufacturing, electricity, gas and water supply', 'Construction', 'Wholesale and retail trade; repair of motor vehicles, motorcycles and personal and household goods', 'Hotels and restaurants', 'Transport, storage and communication', 'Real estate, renting and business activities', 'Public administration and defence, compulsory social security', 'Education', 'Health and social work' and 'Other community, social and personal service activities, private households with employed persons, extra-territorial organisations and bodies'.

\subsection{Macro-level variables}

To separate the effects of macro-economic influence on deregulation of incomes, we additionally controlled for 14 variables for macro-level (Table 3 in Appendix).

Gross domestic product ${ }^{1}$ (GDP) estimated in changes in values (\%) is the final result of the production activity of resident producer units. Gross national income ${ }^{2}$ estimated also in changes in values (\%) represents total primary income receivable by resident institutional units: compensation of employees, taxes on production and imports less subsidies, gross operating surplus, gross mixed income and property income. Value added gross refers to the value generated by any unit engaged in a production activity ${ }^{3}$. Multi-factor productivity ${ }^{4}$ (total-factor productivity) estimated by means of changes in value added (in \%) refers to the part of growth in value added which is explained by the growth in the effects of factors of production (besides contributions of capital and labour force). Labour productivity ${ }^{5}$ estimated by means of changes in value added (in \%) is calculated by dividing gross domestic product (i.e. value added or output) by the number of hours worked to achieve it.

\footnotetext{
${ }^{1}$ Official Statistics of Finland (OSF): Annual national accounts [e-publication]. ISSN=1798-0623. Helsinki: Statistics Finland [referred: 31.8.2018]. Access method: http://www.stat.fi/til/vtp/kas en.html

${ }^{2}$ Official Statistics of Finland (OSF): Annual national accounts [e-publication]. ISSN=1798-0623. Helsinki: Statistics Finland [referred: 31.8.2018]. Access method: http://www.stat.fi/til/vtp/kas_en.html

${ }^{3}$ Statistics: Productivity surveys [e-publication]. ISSN=2343-4333. Helsinki: Statistics Finland [referred: 3.9.2018]. Access method: http://www.stat.fi/til/ttut/kas_en.html

${ }^{4}$ Statistics: Productivity surveys [e-publication]. ISSN=2343-4333. Helsinki: Statistics Finland [referred: 3.9.2018]. Access method: http://www.stat.fi/til/ttut/kas_en.html

${ }^{5}$ Statistics: Productivity surveys [e-publication]. ISSN=2343-4333. Helsinki: Statistics Finland [referred:

3.9.2018]. Access method: http://www.stat.fi/til/ttut/kas_en.html
} 
Contribution of total capital input on TFP and total capital intensity on LP is estimated in changes in value added (in \%). Contribution of total capital is estimated for the Information and Communication Technology, the research and development industry, the machinery and equipment industry, and worked hours' contribution.

\subsection{Statistical method}

We applied multilevel modelling (linear mixed-effects model fit by REML) with individual level only, implemented in a two-step estimation procedure, to investigate macroeconomic influences on redistribution of incomes. We decided on a two-step procedure instead of a simultaneous estimation because it offers a more flexible specification, since all individuallevel effects are allowed to vary across the group of immigrants and the group of natives without imposing any further distributional assumptions (Finch, Bolin, \& Kelley, 2014).

The two-step procedure was implemented as follows. The first step involved estimating the incomes and running fitted value estimations for each observation, and creating the estimated dependent variable (EDV). In the first step, we modelled the fixed relationship between the factors of education, occupation, industry and social benefits affecting increasing or decreasing incomes. To test whether there is a linear relationship between one of the variables/factors and the incomes, we estimated a mixed model with a random intercept and fixed slope. We then predicted the incomes and factors affecting an increase or a decrease in incomes separately for each observation.

We created a two-step design. In the first stage, we estimated the micro-level determinants of incomes for immigrants and natives and adjusted these determinants to influence of social benefits. We used a random intercept and fixed slope model. In the second stage, we estimated macro-level determinants of incomes by means of the EDV and 14 macro macro-economic indicators. We also used the random intercept and fixed slope model. At the second stage, following interaction effect between incomes and education, occupation or industries, differences in incomes between references groups and other groups due to influence of one of 14 indicators have been transformed into percentage proportions.

\section{Conducting research and results}

\subsection{Micro-level determinants}

The results from the first step micro-level determinant estimations reveal quite diverse trends regarding the incomes of immigrants and natives (Table 1).

The intercept shows the estimation of incomes for the reference groups ('higher level of education', 'legislators, senior officials and managers', and 'financial intermediation') calculated separately for immigrants and natives both before and after adjustment for welfare state benefits. According to the estimations, without welfare state benefits, natives have incomes that are almost $47 \%$ higher than those of immigrants $(63,220.28$ euros for natives versus 43,020.38 euros for immigrants). After adjustment for welfare state benefits, the incomes of immigrants remain almost at the same level (43,011.64 euros), while the incomes of natives slightly increase $(63,719.29$ euros). 
Table 1. Linear mixed-effects model fit by REML for incomes and micro-level indicators (tvalue in parentheses) before and after adjustment to influence of social benefits

\begin{tabular}{|c|c|c|c|c|}
\hline & \multicolumn{2}{|c|}{ Before adjustment } & \multicolumn{2}{|c|}{ After adjustment } \\
\hline & Immigrants & Natives & Immigrants & Natives \\
\hline & $43020,38 * * *(9,74)$ & $\begin{array}{l}63220,28 * * * \\
(125,11)\end{array}$ & $43011,64 * * *(10,20)$ & $\begin{array}{l}63719,29 * * * \\
(127,78)\end{array}$ \\
\hline \multicolumn{5}{|c|}{ Higher education (ref. group) } \\
\hline Low and medium education & $-6025,76 * * *(-6,27)$ & $\begin{array}{c}-10041,89 * * *(- \\
56,39)\end{array}$ & $-6584,88 * * *(-7,16)$ & $-9964,10 * * *(-56,71)$ \\
\hline \multicolumn{5}{|c|}{ Legislators, senior officials and managers (ref. group) } \\
\hline Professionals & $5750,21 * *(3,05)$ & $-4683,55 * * *(-17,27)$ & $7302,17 * * *(4,05)$ & $-4301,58 * * *(-16,05)$ \\
\hline $\begin{array}{l}\text { Technicians and associate } \\
\text { professionals }\end{array}$ & $-3361,55(-1,71)$ & $\begin{array}{l}-15309,79 * * *(- \\
54,86)\end{array}$ & $-1912,72(-1,01)$ & $\begin{array}{c}-15125,56 * * *(- \\
54,92)\end{array}$ \\
\hline Clerks & $-6016,23 *(-2,41)$ & $\begin{array}{l}-20555,41 * * *(- \\
56,98)\end{array}$ & $-3853,49(-1,61)$ & $\begin{array}{c}-20267,95 * * *(- \\
56,93)\end{array}$ \\
\hline $\begin{array}{l}\text { Service workers and shop and } \\
\text { market sales workers }\end{array}$ & $-12131,13 * * *(-6,45)$ & $\begin{array}{c}-18641,56 * * *(- \\
61,37)\end{array}$ & $-10190,22 * * *(-5,65)$ & $\begin{array}{c}-18237,37 * * *(- \\
60,81)\end{array}$ \\
\hline $\begin{array}{l}\text { Skilled agricultural and fishery } \\
\text { workers }\end{array}$ & $-15726,02 * *(-2,92)$ & $\begin{array}{c}-28979,40 * * *(- \\
41,98)\end{array}$ & $-14438,01 * *(-2,80)$ & $\begin{array}{c}-28457,88 * * *(- \\
41,79)\end{array}$ \\
\hline Craft and related trades workers & $-5567,63 *(-2,54)$ & $\begin{array}{l}-19128,67 * * *(- \\
57,83)\end{array}$ & $-3566,85(-1,69)$ & $\begin{array}{l}-18455,08 * * *(- \\
56,50)\end{array}$ \\
\hline $\begin{array}{l}\text { Plant and machine operators and } \\
\text { assemblers }\end{array}$ & $-4055,07(-1,72)$ & $\begin{array}{l}-19408,50 * * *(- \\
54,71)\end{array}$ & $-2546,63(-1,13)$ & $\begin{array}{l}-18911,57 * * *(- \\
54,01)\end{array}$ \\
\hline Elementary occupations & $-11002,41 * * *(-5,30)$ & $\begin{array}{l}-20295,28 * * *(- \\
51,45)\end{array}$ & $-7889,95 * * *(-3,95)$ & $\begin{array}{c}-19432,12 * * *(- \\
49,85)\end{array}$ \\
\hline \multicolumn{5}{|c|}{ Financial intermediation (ref. group) } \\
\hline $\begin{array}{l}\text { Agriculture, hunting and forestry, } \\
\text { fishing }\end{array}$ & $-15520,31 *(-2,30)$ & $\begin{array}{c}-22295,44 * * *(- \\
28,11)\end{array}$ & $-14736,59 *(-2,28)$ & $\begin{array}{c}-22172,97 * * *(- \\
28,34)\end{array}$ \\
\hline $\begin{array}{l}\text { Mining and quarrying, } \\
\text { manufacturing, electricity, gas and } \\
\text { water supply }\end{array}$ & $-5759,72(-1,28)$ & $-4808,34 * * *(-9,43)$ & $-4379,31(-1,02)$ & $-4726,11 * * *(-9,39)$ \\
\hline Construction & $-10048,05 *(-2,13)$ & $\begin{array}{c}-16472,32 * * *(- \\
29,76)\end{array}$ & $-9461,01 *(-2,10)$ & $\begin{array}{c}-16044,33 * * *(- \\
29,38)\end{array}$ \\
\hline $\begin{array}{l}\text { Wholesale and retail trade; repair } \\
\text { of motor vehicles, motorcycles and } \\
\text { personal and household goods }\end{array}$ & $-7172,57(-1,60)$ & $\begin{array}{l}-15571,38 * * *(- \\
30,00)\end{array}$ & $-6150,36(-1,44)$ & $\begin{array}{c}-15395,75 * * *(- \\
30,07)\end{array}$ \\
\hline Hotels and restaurants & $-14298,60 * *(-3,12)$ & $\begin{array}{c}-20330,47 * * *(- \\
31,40)\end{array}$ & $-12887,41 * *(-2,94)$ & $\begin{array}{c}-19935,14 * * *(- \\
31,21)\end{array}$ \\
\hline $\begin{array}{l}\text { Transport, storage and } \\
\text { communication }\end{array}$ & $-7381,72(-1,62)$ & $\begin{array}{c}-11323,62 * * *(- \\
21,69)\end{array}$ & $-6421,17(-1,48)$ & $\begin{array}{l}-11180,62 * * *(- \\
21,71)\end{array}$ \\
\hline $\begin{array}{l}\text { Real estate, renting and business } \\
\text { activities }\end{array}$ & $-13733,69 * *(-3,04)$ & $\begin{array}{c}-18254,12 * * *(- \\
35,28)\end{array}$ & $-13314,96 * *(-3,09)$ & $\begin{array}{c}-17593,55 * * *(- \\
34,47)\end{array}$ \\
\hline $\begin{array}{l}\text { Public administration and defence, } \\
\text { compulsory social security }\end{array}$ & $-2194,24(-0,44)$ & $-8667,88 * * *(-15,43)$ & $-2466,33(-0,52)$ & $-8600,00 * * *(-15,53)$ \\
\hline Education & $-12218,35 * *(-2,68)$ & $\begin{array}{c}-16249,52 * * *(- \\
29,90)\end{array}$ & $-10088,00 *(-2,31)$ & $\begin{array}{c}-15488,97 * * *(- \\
28,88)\end{array}$ \\
\hline Health and social work & $-5350,64(-1,20)$ & $\begin{array}{c}-14645,57 * * * *(- \\
28,75)\end{array}$ & $-4900,65(-1,15)$ & $\begin{array}{c}-14245,64 * * *(- \\
28,35)\end{array}$ \\
\hline $\begin{array}{l}\text { Other community, social and } \\
\text { personal service activities, private } \\
\text { households with employed persons, } \\
\text { extra-territorial organisations and } \\
\text { bodies }\end{array}$ & $-18935,42 * * *(-4,12)$ & $\begin{array}{c}-23899,10 * * *(- \\
42,82)\end{array}$ & $-17256,81 * * *(-3,93)$ & $\begin{array}{c}-23080,75 * * *(- \\
41,90)\end{array}$ \\
\hline \multicolumn{5}{|c|}{ Benefits } \\
\hline Unemployment benefits & - & - & $-2,26 * * *(-14,14)$ & $-1,65 * * *(-40,29)$ \\
\hline Old-age benefits & - & - & $-0,86 * *(-3,17)$ & $-0,55 * * *(-26,41)$ \\
\hline Survivor' benefits & - & - & $-0,20(-0,23)$ & $-0,30 * * *(-3,58)$ \\
\hline Sickness benefits & - & - & $-0,65(-0,96)$ & $-1,14 * * *(-14,95)$ \\
\hline Disability benefits & - & - & $-1,17 * *(-3,13)$ & $-0,67 * * *(-16,69)$ \\
\hline Education-related allowances & - & - & $-1,96 * * *(-5,76)$ & $-1,21 * * *(-16,03)$ \\
\hline LogLik & $-27831,07$ & -1228454 & $-27713,74$ & -1226978 \\
\hline $\mathbf{N}$ & 2484 & 107501 & 2484 & 107501 \\
\hline
\end{tabular}

Source: own calculations are based on the European Union Statistics on Income and Living Conditions (EU-SILC) cross-sectional micro-data for Finland for the period of 2004 to 2016 (a sample of 2,484 cases for immigrants and 107,501 cases for natives)

The coefficients presented in Table 2 show the extent to which intercepts change for each group when compared to the reference groups. The findings clearly confirm that natives 
with higher levels of education working in the position of legislators, senior officials and managers in the sphere of financial intermediation have the highest levels of incomes, while among immigrants, professionals have slightly higher incomes than legislators, senior officials and managers. The results confirm that received benefits (unemployment benefits, old-age benefits, survivor benefits, sickness benefits, disability benefits and education-related allowances) slightly decrease incomes both for immigrants and for natives. For immigrants, this negative effect is slightly higher than it is for natives with regard to unemployment benefits, disability benefits and education-related allowances.

\subsection{Macro-level determinants and compositional effects}

In the second step, the Level 1 estimates based on the EDV were regressed on the macro-economic indicators. Following Lewis and Linzer (2005), estimates obtained after the Level 1 regression were inserted into the Level 2 model in the quality of the estimated dependent variable (EDV). Tables 2, 3 and 4 show the elasticity estimates calculated for incomes and the macro-level economic determinants considered as without influence of welfare state benefits following adjustment for this influence (all calculations).

\subsubsection{Education}

Regarding the effect of education upon income redistribution (Table 2), the findings confirm that a $1 \%$ increase in gross domestic product and gross national income is associated with a $0.5-0.6 \%$ increase in the incomes of both immigrants and natives with low and medium education in comparison to the population with higher education. The effect from the adjustment of incomes with regard to welfare state benefits remains unchanged for both immigrants and for natives.

Table 2. Elasticity estimates for educational groups and macro-economic indicators before and after adjustment to influence of social benefits (based on linear mixed-effects model fit by REML)

\begin{tabular}{|c|c|c|c|c|c|c|c|c|c|c|c|c|c|c|}
\hline \multirow{2}{*}{$\begin{array}{l}\text { Higher } \\
\text { education (ref. } \\
\text { group) }\end{array}$} & \multirow{2}{*}{$\begin{array}{c}\text { Gross } \\
\text { domes } \\
\text { tic } \\
\text { produ } \\
\text { ct }\end{array}$} & \multirow{2}{*}{$\begin{array}{c}\text { Gross } \\
\text { natio } \\
\text { nal } \\
\text { incom } \\
\text { e }\end{array}$} & \multirow{2}{*}{$\begin{array}{c}\text { Value } \\
\text { added } \\
\text { chang } \\
\text { e, \% }\end{array}$} & \multirow{2}{*}{$\begin{array}{l}\text { Labour } \\
\text { product } \\
\text { ivity, \% }\end{array}$} & \multirow{2}{*}{$\begin{array}{c}\text { Multi } \\
- \\
\text { factor } \\
\text { produ } \\
\text { ctivity } \\
, \%\end{array}$} & \multicolumn{4}{|c|}{$\begin{array}{l}\text { Total-factor productivity, } \\
\text { contribution: }\end{array}$} & \multicolumn{5}{|c|}{ Labour productivity, contribution: } \\
\hline & & & & & & $\begin{array}{c}\text { Total } \\
\text { capita } \\
1 \\
\text { input, } \\
\%\end{array}$ & $\begin{array}{c}\text { ICT- } \\
\text { capita } \\
1 \\
\text { input, } \\
\%\end{array}$ & $\underset{\%}{\mathbf{R} \& D}$ & $\begin{array}{c}\text { Machi } \\
\text { nery } \\
\text { and } \\
\text { equip } \\
\text { ment, } \\
\%\end{array}$ & $\begin{array}{c}\text { Work } \\
\text { ed } \\
\text { hours, } \\
\%\end{array}$ & $\begin{array}{l}\text { Capit } \\
\text { al } \\
\text { intensi } \\
\text { ty, } \%\end{array}$ & $\begin{array}{c}\text { ICT- } \\
\text { capita } \\
1 \\
\text { intensi } \\
\text { ty, \% }\end{array}$ & $\begin{array}{c}\text { R\&D } \\
\text { intensi } \\
\text { ty, \% }\end{array}$ & $\begin{array}{c}\text { Equip } \\
\text { ment } \\
\text { and } \\
\text { machi } \\
\text { nery } \\
\text { capita } \\
\text { l } \\
\text { intens } \\
\text { ity, \% }\end{array}$ \\
\hline \multicolumn{15}{|c|}{ Without adjustment to welfare state benefits } \\
\hline $\begin{array}{l}\text { Immigrants, } \\
\text { low and } \\
\text { medium } \\
\text { education }\end{array}$ & 0.58 & 0.69 & 0.35 & 0.05 & 0 & 0.09 & 0.32 & 0.20 & 0.25 & 0.02 & -0.01 & 0.16 & 0.03 & -0.07 \\
\hline $\begin{array}{l}\text { Natives, low } \\
\text { and medium } \\
\text { education }\end{array}$ & 0.51 & 0.58 & 0.49 & 0.53 & 0.35 & 0.08 & 0.31 & 0.21 & 0.17 & 0.02 & 0.03 & 0.31 & 0.13 & 0.00 \\
\hline \multicolumn{15}{|c|}{ After adjustment to welfare state benefits } \\
\hline $\begin{array}{l}\text { Immigrants, } \\
\text { low and } \\
\text { medium } \\
\text { education }\end{array}$ & 0.57 & 0.68 & 0.34 & 0.03 & -0.02 & 0.09 & 0.31 & 0.20 & 0.26 & 0.02 & 0.00 & 0.15 & 0.04 & -0.07 \\
\hline $\begin{array}{l}\text { Natives, low } \\
\text { and medium } \\
\text { education }\end{array}$ & 0.51 & 0.58 & 0.49 & 0.53 & 0.35 & 0.08 & 0.31 & 0.21 & 0.17 & 0.02 & 0.03 & 0.31 & 0.13 & 0.00 \\
\hline
\end{tabular}


Source: own calculations are based on the European Union Statistics on Income and Living Conditions (EU-SILC) cross-sectional micro-data for Finland for the period of 2004 to 2016 (a sample of 2,484 cases for immigrants and 107,501 cases for natives)

Almost the same tendency is seen for the influence of a $1 \%$ change in value added upon the increase in incomes (given a $0.3-0.4 \%$ increase in the incomes of the population groups with low and medium education). However, growth of $1 \%$ of value added on TFP and labour productivity produces a slightly more positive effect for natives with low and medium education. For immigrants this effect remains almost unchanged.

When considering the effect of the contribution of capital in value added, the findings confirm that a $0.01 \%$ change in value added on contribution of total capital input, ICT-capital input, R\&D and worked hours' contribution to the TFP produces almost the same effect with regard to increasing incomes for both immigrants and natives with low and medium education. However, the contribution of machinery and equipment to TFP and contribution of ICT-capital intensity and R\&D intensity on labour productivity is associated with a slightly more positive effect on increasing the incomes of immigrants with low and medium education than for natives.

\subsubsection{Occupation}

When considering the effect of occupation upon income redistribution (Table 3), the findings confirm a general increase in the incomes of all the occupational groups in comparison to legislators, senior officials and managers (ref. group) due to growth in gross domestic product, gross national income, value added, TFP and labour productivity. A $1 \%$ increase in gross domestic product and gross national income is associated with a $2-3 \%$ increase in the incomes of clerks, skilled agricultural and fishery workers and elementary occupations among immigrants. This effect is even slightly more positive for immigrants than it is for natives with the same occupations. After adjustment for welfare state benefits, the findings confirm a slight positive influence upon the increase in the incomes of immigrants in all of the occupational groups. For natives, the effect from the adjustment of incomes for welfare state benefits remains unchanged.

Table 3. Elasticity estimates for occupational groups and macro-economic indicators before and after adjustment to influence of social benefits (based on linear mixed-effects model fit by REML)

\begin{tabular}{|c|c|c|c|c|c|c|c|c|c|c|c|c|c|c|c|}
\hline \multirow{2}{*}{\multicolumn{2}{|c|}{$\begin{array}{l}\text { Legislators, senior officials and } \\
\text { managers (ref. group) }\end{array}$}} & \multirow{2}{*}{$\begin{array}{c}\text { Gross } \\
\text { domest } \\
\text { ic } \\
\text { produc } \\
\text { t }\end{array}$} & \multirow{2}{*}{$\begin{array}{c}\text { Gross } \\
\text { nation } \\
\text { al } \\
\text { income }\end{array}$} & \multirow{2}{*}{$\begin{array}{c}\text { Value } \\
\text { added } \\
\text { change } \\
, \%\end{array}$} & \multirow{2}{*}{$\begin{array}{c}\text { Labou } \\
\text { r } \\
\text { produc } \\
\text { tivity, } \\
\%\end{array}$} & \multirow{2}{*}{$\begin{array}{c}\text { Multi- } \\
\text { factor } \\
\text { produc } \\
\text { tivity, } \\
\%\end{array}$} & \multicolumn{4}{|c|}{$\begin{array}{c}\text { Total-factor productivity, } \\
\text { contribution: }\end{array}$} & \multicolumn{5}{|c|}{ Labour productivity, contribution: } \\
\hline & & & & & & & $\begin{array}{c}\text { Total } \\
\text { capit } \\
\text { al } \\
\text { input } \\
, \%\end{array}$ & $\begin{array}{c}\text { ICT- } \\
\text { capit } \\
\text { al } \\
\text { input } \\
, \%\end{array}$ & $\begin{array}{l}\text { R\&D } \\
, \%\end{array}$ & $\begin{array}{c}\text { Mac } \\
\text { hiner } \\
\text { y and } \\
\text { equip } \\
\text { ment, } \\
\%\end{array}$ & $\begin{array}{c}\text { Wor } \\
\text { ked } \\
\text { hour } \\
\text { s, \% }\end{array}$ & $\begin{array}{l}\text { Capit } \\
\text { al } \\
\text { inten } \\
\text { sity, } \\
\%\end{array}$ & $\begin{array}{c}\text { ICT- } \\
\text { capit } \\
\text { al } \\
\text { inten } \\
\text { sity, } \\
\%\end{array}$ & $\begin{array}{c}\text { R\&D } \\
\text { inten } \\
\text { sity, } \\
\%\end{array}$ & $\begin{array}{c}\text { Equi } \\
\text { pme } \\
\text { nt } \\
\text { and } \\
\text { mach } \\
\text { inery } \\
\text { capit } \\
\text { al } \\
\text { inten } \\
\text { sity, } \\
\%\end{array}$ \\
\hline \multicolumn{16}{|c|}{ Without adjustment to welfare state benefits } \\
\hline & Professionals & 0.96 & 1.21 & 2.1 & 3.59 & 2.82 & 0.21 & 0.72 & 0.97 & 0.16 & 0.04 & 0.21 & 1.17 & 0.84 & 0.25 \\
\hline & $\begin{array}{l}\text { Technicians and associate } \\
\text { professionals }\end{array}$ & 1.39 & 1.63 & 2.22 & 3.59 & 3 & 0.19 & 0.67 & 0.87 & 0.11 & 0.05 & 0.17 & 0.91 & 0.65 & -0.11 \\
\hline & Clerks & 2.08 & 2.63 & 3.41 & 5.49 & 4.4 & 0.35 & 1.40 & 1.33 & 0.42 & 0.07 & 0.23 & 1.77 & 0.92 & 0.17 \\
\hline .0 & $\begin{array}{l}\text { Service workers and shop and } \\
\text { market sales workers }\end{array}$ & 1.18 & 1.42 & 1.89 & 3.43 & 2.43 & 0.28 & 1.01 & 1.17 & 0.31 & 0.04 & 0.26 & 1.33 & 0.84 & 0.12 \\
\hline & $\begin{array}{l}\text { Skilled agricultural and fishery } \\
\text { workers }\end{array}$ & 2.85 & 3.44 & 4.21 & 6.73 & 5.15 & 0.43 & 1.57 & 1.64 & 0.50 & 0.10 & 0.32 & 1.85 & 1.24 & -0.03 \\
\hline & Craft and related trades workers & 0.64 & 0.81 & 1.53 & 3.03 & 1.95 & 0.27 & 1.05 & 1.10 & 0.35 & 0.02 & 0.28 & 1.47 & 0.88 & 0.35 \\
\hline
\end{tabular}




\begin{tabular}{|c|c|c|c|c|c|c|c|c|c|c|c|c|c|c|c|}
\hline & $\begin{array}{l}\text { Plant and machine operators and } \\
\text { assemblers }\end{array}$ & 1.59 & 1.76 & 2.25 & 3.38 & 2.49 & 0.28 & 0.93 & 1.20 & 0.38 & 0.06 & 0.25 & 1.25 & 0.90 & 0.03 \\
\hline & Elementary occupations & 2.74 & 3.02 & 3.26 & 4.85 & 3.42 & 0.45 & 1.61 & 1.60 & 0.98 & 0.09 & 0.32 & 1.92 & 1.13 & 0.24 \\
\hline & Professionals & 1.21 & 1.56 & 1.61 & 2.26 & 1.48 & 0.31 & 1.13 & 1.09 & 0.60 & 0.05 & 0.16 & 1.29 & 0.60 & 0.05 \\
\hline & $\begin{array}{l}\text { Technicians and associate } \\
\text { professionals }\end{array}$ & 1.55 & 1.94 & 1.94 & 2.65 & 1.76 & 0.34 & 1.24 & 1.19 & 0.63 & 0.06 & 0.18 & 1.40 & 0.67 & 0.05 \\
\hline & Clerks & 2.06 & 2.49 & 2.42 & 3.14 & 2.11 & 0.40 & 1.47 & 1.34 & 0.82 & 0.08 & 0.19 & 1.60 & 0.75 & 0.03 \\
\hline$\sum_{:=}^{n}$ & $\begin{array}{l}\text { Service workers and shop and } \\
\text { market sales workers }\end{array}$ & 2.18 & 2.63 & 2.57 & 3.37 & 2.3 & 0.42 & 1.52 & 1.38 & 0.87 & 0.09 & 0.20 & 1.65 & 0.77 & 0.03 \\
\hline 离 & $\begin{array}{l}\text { Skilled agricultural and fishery } \\
\text { workers }\end{array}$ & 2.47 & 2.95 & 2.85 & 3.68 & 2.45 & 0.47 & 1.73 & 1.52 & 1.02 & 0.10 & 0.22 & 1.86 & 0.86 & 0.05 \\
\hline & Craft and related trades workers & 2.1 & 2.55 & 2.52 & 3.26 & 2.13 & 0.44 & 1.60 & 1.42 & 0.98 & 0.09 & 0.21 & 1.76 & 0.83 & 0.10 \\
\hline & $\begin{array}{l}\text { Plant and machine operators and } \\
\text { assemblers }\end{array}$ & 2.56 & 3.11 & 3.04 & 3.92 & 2.58 & 0.50 & 1.86 & 1.62 & 1.17 & 0.10 & 0.25 & 2.02 & 0.94 & 0.13 \\
\hline & Elementary occupations & 2.15 & 2.62 & 2.55 & 3.31 & 2.19 & 0.43 & 1.58 & 1.44 & 0.89 & 0.09 & 0.21 & 1.71 & 0.82 & 0.04 \\
\hline \multicolumn{16}{|c|}{ After adjustment to welfare state benefits } \\
\hline \multirow{8}{*}{ 起 } & Professionals & 0.99 & 1.25 & 2.14 & 3.62 & 2.86 & 0.21 & 0.72 & 0.98 & 0.15 & 0.04 & 0.21 & 1.17 & 0.84 & 0.24 \\
\hline & $\begin{array}{l}\text { Technicians and associate } \\
\text { professionals }\end{array}$ & 1.43 & 1.67 & 2.25 & 3.63 & 3.05 & 0.19 & 0.66 & 0.86 & 0.11 & 0.06 & 0.17 & 0.89 & 0.64 & -0.13 \\
\hline & Clerks & 2.11 & 2.65 & 3.42 & 5.52 & 4.39 & 0.35 & 1.43 & 1.35 & 0.43 & 0.07 & 0.24 & 1.80 & 0.93 & 0.16 \\
\hline & $\begin{array}{l}\text { Service workers and shop and } \\
\text { market sales workers }\end{array}$ & 1.22 & 1.45 & 1.90 & 3.45 & 2.45 & 0.28 & 1.02 & 1.18 & 0.30 & 0.04 & 0.26 & 1.34 & 0.84 & 0.11 \\
\hline & $\begin{array}{l}\text { Skilled agricultural and fishery } \\
\text { workers }\end{array}$ & 2.86 & 3.42 & 4.21 & 6.73 & 5.19 & 0.42 & 1.55 & 1.61 & 0.49 & 0.09 & 0.31 & 1.82 & 1.21 & -0.03 \\
\hline & Craft and related trades workers & 0.67 & 0.82 & 1.53 & 3.03 & 1.94 & 0.27 & 1.06 & 1.10 & 0.34 & 0.02 & 0.28 & 1.48 & 0.88 & 0.35 \\
\hline & $\begin{array}{l}\text { Plant and machine operators and } \\
\text { assemblers }\end{array}$ & 1.62 & 1.77 & 2.26 & 3.38 & 2.49 & 0.28 & 0.94 & 1.21 & 0.39 & 0.06 & 0.25 & 1.26 & 0.91 & 0.02 \\
\hline & Elementary occupations & 2.81 & 3.09 & 3.33 & 4.91 & 3.48 & 0.45 & 1.63 & 1.61 & 0.99 & 0.09 & 0.32 & 1.93 & 1.14 & 0.23 \\
\hline & Professionals & 1.22 & 1.56 & 1.61 & 2.26 & 1.48 & 0.31 & 1.13 & 1.10 & 0.60 & 0.05 & 0.16 & 1.29 & 0.60 & 0.05 \\
\hline & $\begin{array}{l}\text { Technicians and associate } \\
\text { professionals }\end{array}$ & 1.55 & 1.94 & 1.95 & 2.65 & 1.76 & 0.34 & 1.25 & 1.19 & 0.64 & 0.06 & 0.18 & 1.40 & 0.67 & 0.05 \\
\hline & Clerks & 2.06 & 2.49 & 2.42 & 3.14 & 2.11 & 0.40 & 1.47 & 1.34 & 0.82 & 0.08 & 0.19 & 1.60 & 0.75 & 0.03 \\
\hline & $\begin{array}{l}\text { Service workers and shop and } \\
\text { market sales workers }\end{array}$ & 2.18 & 2.63 & 2.57 & 3.36 & 2.29 & 0.42 & 1.52 & 1.38 & 0.87 & 0.09 & 0.20 & 1.65 & 0.77 & 0.03 \\
\hline & $\begin{array}{l}\text { Skilled agricultural and fishery } \\
\text { workers }\end{array}$ & 2.47 & 2.96 & 2.85 & 3.68 & 2.45 & 0.47 & 1.73 & 1.52 & 1.02 & 0.10 & 0.22 & 1.86 & 0.86 & 0.05 \\
\hline & Craft and related trades workers & 2.10 & 2.55 & 2.52 & 3.25 & 2.12 & 0.44 & 1.61 & 1.43 & 0.98 & 0.09 & 0.22 & 1.77 & 0.83 & 0.10 \\
\hline & $\begin{array}{l}\text { Plant and machine operators and } \\
\text { assemblers }\end{array}$ & 2.56 & 3.11 & 3.04 & 3.92 & 2.58 & 0.50 & 1.86 & 1.62 & 1.17 & 0.10 & 0.25 & 2.02 & 0.94 & 0.13 \\
\hline & Elementary occupations & 2.14 & 2.61 & 2.54 & 3.29 & 2.17 & 0.43 & 1.58 & 1.44 & 0.89 & 0.09 & 0.21 & 1.72 & 0.83 & 0.05 \\
\hline
\end{tabular}

Source: own calculations are based on the European Union Statistics on Income and Living Conditions (EU-SILC) cross-sectional micro-data for Finland for the period of 2004 to 2016 (a sample of 2,484 cases for immigrants and 107,501 cases for natives)

For other occupational groups of natives, an increase in gross domestic product and gross national income has a larger positive effect (e.g., an approximate 2-3\% increase for clerks, service and market sales workers, skilled agricultural and fishery workers, craft workers, plant and machine operators and elementary occupations). These results are described for estimations without adjustment for welfare state benefits. After adjustment, the findings confirm that welfare state benefits exert a slight positive influence upon an increase in the incomes of immigrants in all occupational groups. For natives, the effect from adjustment of incomes to welfare state benefits remains unchanged.

Among immigrants, a $1 \%$ increase in value added results in a higher increase in the incomes of clerks $(>3 \%)$, for skilled agricultural and fishery workers $(>4 \%)$ and for elementary occupations $(>3 \%)$. These estimations are slightly larger for immigrants than for natives. However, for natives a $1 \%$ increase in value added has a more significant effect on the increase in the incomes of plant and machine operators and assemblers $(>3 \%)$ and skilled agricultural and fishery workers $(>2 \%)$. After adjustment for welfare state benefits, this positive effect upon the increase in incomes is seen for all immigrant occupational groups. For natives, the adjustment of incomes for welfare state benefits has zero effect, e.g., rates of change remain the same.

A $1 \%$ increase of value added on labour productivity is seen as having the highest effect for immigrant clerks (5.49\% versus $3.14 \%$ for natives), skilled agricultural and fishery workers $(6.73 \%$ versus $3.68 \%$ for natives) and elementary occupations (4.85\% versus $3.31 \%$ for natives). On the contrary, for natives a $1 \%$ increase of value added on labour productivity 
provides a more positive effect on the increase in the incomes of clerks, service and market sales workers, skilled agricultural and fishery workers, craft workers, plant and machine operators and elementary occupations. Native craft workers and plant and machine operators have a slightly higher positive influence upon the increase in incomes than immigrants. After adjustment for welfare state benefits, an increase in incomes is once again seen for immigrants, while it is unchanged for natives.

A $1 \%$ increase of value added on TFP generally has smaller effect on the increase in incomes than is seen from labour productivity. Once again clerks, skilled agricultural and fishery workers and elementary occupations have a higher increase in incomes due to the increase in TFP than natives. Among natives, clerks, service and market sales workers, skilled agricultural and fishery workers, craft workers, plant and machine operators and elementary occupations have an increase in incomes of over $2 \%$ due to increasing TFP. Craft workers and plant and machine operators have a slightly more positive effect from value added on TFP than the same occupational groups among immigrants. After adjustment for welfare state benefits, the effect is slightly more positive for immigrants, while it remains unchanged for natives.

A $0.01 \%$ increase in the contribution of ICT-capital input and R\&D on TFP exerts a more positive effect on the increase in the incomes of natives for all the occupational groups $(>1 \%)$. For immigrants, a more positive effect is seen for skilled agricultural and fishery workers and elementary occupations $(>1.5 \%)$. Contribution of machinery and equipment to TFP gives an over $1 \%$ increase in incomes for skilled agricultural and fishery workers and plant and machine operators. In addition, a $0.01 \%$ increase in the contribution of ICT-capital intensity to labour productivity results in an increase of over $1 \%$ in the incomes of immigrants from all occupational groups except technicians and associate professionals. For natives, this effect is slightly more pronounced giving a higher increase in the incomes of skilled agricultural and fishery workers $(>1 \%)$, craft workers $(>1 \%)$ and plant and machine operators $(>2 \%)$. On the contrary, the contribution of $R \& D$ intensity has a slightly more positive effect $(>1 \%)$ on the increase in the incomes of skilled immigrant agricultural and fishery workers and elementary occupations.

\subsubsection{Industry}

When considering the effect of industry upon the redistribution of incomes (Table 4), the findings confirm that increases in gross domestic product, gross national income, value added, TFP and labour productivity essentially lead to increased incomes for immigrants in the industries of agriculture, manufacturing, construction, hotels and restaurants. After adjustment for welfare state benefits, slight changes (both negative and positive) in the incomes of immigrants are seen.

The contribution of ICT-capital input and R\&D (TFP) provides a higher increase in the incomes of immigrants in the spheres of agriculture, manufacturing and hotels and restaurants. The contribution of machinery and equipment (TFP) results in a more positive effect on the increase in the incomes of immigrants in all industries and in particular for the spheres of real estate, renting and business activities, public administration and defence, and compulsory social security. The contribution of ICT-capital intensity (LP) has a more positive effect on the increase in the incomes of immigrants in the spheres of agriculture, real estate, renting and business activities, public administration and defence, compulsory social security and health and social work. Bilan et al. (2019) have come to similar conclusions when finding that ICT factors have influence on the main financial results and economic progress. 
Table 4. Elasticity estimates for industries and macro-economic indicators before and after adjustment to influence of social benefits (based on linear mixed-effects model fit by REML)

\begin{tabular}{|c|c|c|c|c|c|c|c|c|c|c|c|c|c|}
\hline \multirow{2}{*}{$\begin{array}{c}\text { Gross } \\
\text { domest } \\
\text { ic } \\
\text { produc } \\
\text { t }\end{array}$} & \multirow{2}{*}{$\begin{array}{c}\text { Gros } \\
\text { s } \\
\text { nati } \\
\text { onal } \\
\text { inco } \\
\text { me }\end{array}$} & \multirow{2}{*}{$\begin{array}{c}\text { Valu } \\
\text { e } \\
\text { adde } \\
\text { d } \\
\text { chan } \\
\text { ge, } \\
\%\end{array}$} & \multirow{2}{*}{$\begin{array}{c}\text { Lab } \\
\text { our } \\
\text { prod } \\
\text { uctiv } \\
\text { ity, } \\
\%\end{array}$} & \multirow{2}{*}{$\begin{array}{c}\text { Mult } \\
\text { i- } \\
\text { facto } \\
\text { r } \\
\text { prod } \\
\text { uctiv } \\
\text { ity, } \\
\%\end{array}$} & \multicolumn{4}{|c|}{$\begin{array}{l}\text { Total-factor productivity, } \\
\text { contribution: }\end{array}$} & \multicolumn{5}{|c|}{$\begin{array}{l}\text { Labour productivity, } \\
\text { contribution: }\end{array}$} \\
\hline & & & & & $\begin{array}{c}\text { Total } \\
\text { capit } \\
\text { al } \\
\text { input } \\
, \%\end{array}$ & $\begin{array}{c}\text { ICT- } \\
\text { capit } \\
\text { al } \\
\text { input } \\
, \%\end{array}$ & $\begin{array}{c}\text { R\&D } \\
, \%\end{array}$ & $\begin{array}{c}\text { Mac } \\
\text { hiner } \\
\text { y } \\
\text { and } \\
\text { equi } \\
\text { pme } \\
\text { nt, } \\
\%\end{array}$ & $\begin{array}{l}\text { Wor } \\
\text { ked } \\
\text { hour } \\
\text { s, \% }\end{array}$ & $\begin{array}{c}\text { Capi } \\
\text { tal } \\
\text { inten } \\
\text { sity, } \\
\%\end{array}$ & $\begin{array}{c}\text { ICT- } \\
\text { capit } \\
\text { al } \\
\text { inten } \\
\text { sity, } \\
\%\end{array}$ & $\begin{array}{c}\text { R\&D } \\
\text { inten } \\
\text { sity, } \\
\%\end{array}$ & $\begin{array}{c}\text { Equi } \\
\text { pme } \\
\text { nt } \\
\text { and } \\
\text { mac } \\
\text { h., \% }\end{array}$ \\
\hline
\end{tabular}

Without adjustment to welfare state benefits

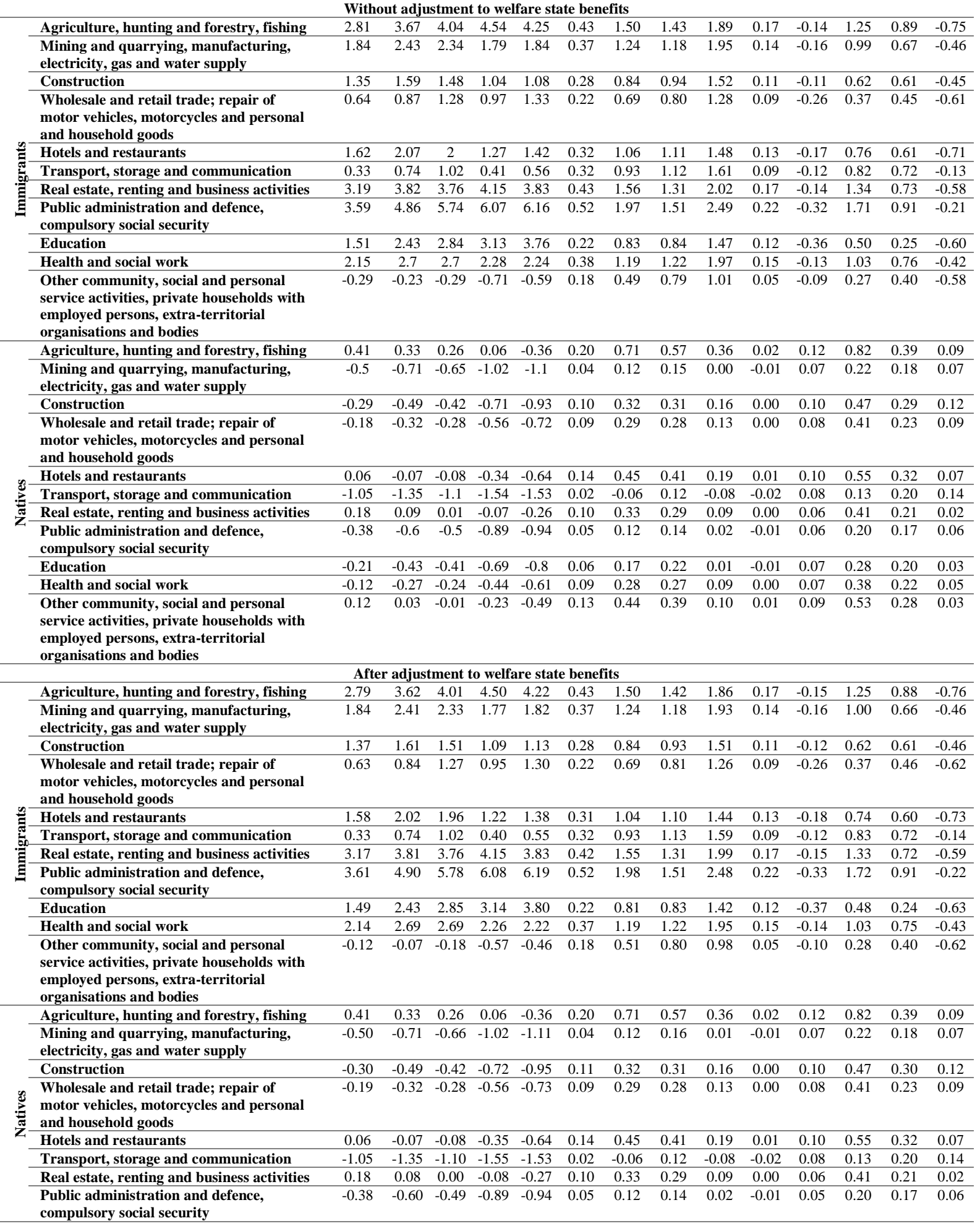




\begin{tabular}{|c|c|c|c|c|c|c|c|c|c|c|c|c|c|c|}
\hline Education & -0.20 & -0.42 & -0.41 & -0.69 & -0.80 & 0.06 & 0.17 & 0.22 & 0.01 & -0.01 & 0.07 & 0.29 & 0.20 & 0.03 \\
\hline $\begin{array}{l}\text { Other community, social and personal } \\
\text { service activities, private households with } \\
\text { employed persons, extra-territorial } \\
\text { organisations and bodies }\end{array}$ & 0.11 & 0.02 & -0.02 & -0.24 & -0.50 & 0.13 & 0.44 & 0.40 & 0.10 & 0.01 & 0.09 & 0.53 & 0.28 & 0.03 \\
\hline
\end{tabular}

Source: own calculations are based on the European Union Statistics on Income and Living Conditions (EU-SILC) cross-sectional micro-data for Finland for the period of 2004 to 2016 (a sample of 2,484 cases for immigrants and 107,501 cases for natives)

\section{Conclusion}

The main aim of this study was to find more specific evidence-based information on the classical question of how the economic growth and productivity of a country contributes to growth of income and how the factors of education, occupation and industry account for development of the incomes of immigrants and natives in a country due to influence of economic growth and productivity. In the frame of an aggregate production function approach, we estimated the influence of macro-economic indicators, productivity and welfare state provision upon income dynamics among immigrants and natives.

The results confirm that natives have incomes that almost are $47 \%$ higher than immigrants and the structure of incomes differs between occupational groups among immigrants and natives, supporting the results of previous studies (Barth, Bernt \& Raaum, 2004, 2006; Gustafsson \& Zheng, 2006; Cortés, 2008; Peri \& Sparber, 2009; Ottaviano \& Peri, 2012; Hammarstedt, 2003; Galloway, 2008). This result is in line with the results of Bresnahan (1999) and Beadury, Green and Sand (2013) who revealed that growing inequalities in the labour market can be seen in wage differentials both at the bottom and the top of the wage distribution. Dualization of the labour market via atypical or 'precarious' employment leads to a widening gap between high-skilled and low-skilled workers and further job polarization and wage differentials between immigrants and natives.

Another important tendency that must be taken into account is that in Finland the development of productivity growth has steadily slowed down after the mid-1990s after a period of relatively steady productivity growth during the previous two decades. Since 2000, both TFP and labour productivity growth trends have clearly slowed down. Though the productivity growth still remains positive, it is the direction of the trend which is alarming.

The results of this study confirm that productivity increases contribute to wages but at a different rate for immigrants and natives. One of the possible explanations for the differentiation of wages lies in the course of discussion concerning imperfect substitution between immigrants and natives (Borjas, 1987; Card \& Lemieux, 2001; Ottaviano \& Peri, 2012; Manacorda, Manning \& Wadsworth, 2012), when the labour positions of immigrants and natives at the labour market are pre-assumed in the frame of different imperfect-competition segments. On the other hand, a structural model of production, which combines workers of different skills with capital, represents the combination of immigrant and native labour in the frame of the labour market equilibrium framework as the interaction between production factors (Borjas, 2003; Aydemir \& Borjas, 2007, 2011; Ottaviano \& Peri, 2008; D’Amuri, Ottaviano \& Peri, 2010; Cohen-Goldner \& Paserman, 2011; Card, 2001).

Occupation has been revealed to be another important parameter for the determination of wage effects from economic growth and productivity both for immigrants and natives. Similarly, Markusen (2013) finds a positive and economically and statistically significant relationship between the skill associated with a specific good, the capital-intensity in production and its income elasticity of demand in consumption. In the evidence provided by Markusen (2013), the behaviour of trade to GDP ratios and the role of intra-country income distribution depends on the demand and supply sides of general equilibrium, when higher mark-ups and 
higher price levels explain higher per capita incomes. Ortega and Peri (2014) also found that the positive effect of migration is clearly distinct from the effects of institutional quality; the estimated effect of migration on income operates mainly by increasing TFP, which appears to reflect increased diversity in productive skills and, to some extent, a higher rate of innovation. As Lewis (2003) has found, increases in the relative supply of a particular skill group (e.g., immigrant labour) and local factor supplies lead to increases in relative factor intensity, that in turn affect increases in wages. This kind of effect was also clear in our study.

On the other hand, we found that the factor of industry is meaningful for the growth of incomes from economic regulators (gross domestic product, gross national income, value added, TFP and labour productivity) only for immigrants, while showing zero effect for natives. The interpretation would be that international productivity differences are so large in some industries that replacing efficiently produced imports with inefficiently produced domestic substitutes in these industries would imply extreme costs.

The first possible explanation for this result lies in the argument that local industry structures responses to immigration-induced supply shocks as the absorption of unskilled immigrants takes place within the industries of high-immigrant cities, rather than between industries. Production technology rapidly adapts to the local mix of workers. The issue of wage determination inside a specific industry due to the influence of macro-economic growth and productivity depends on the situation, and how firms in a given industry can adapt their production technology so closely to local supplies of different types of labour without substantial changes in relative wages.

The second possible explanation of the obtained results lies in the course of discussion about the influence of international trade dynamics upon redistribution of incomes. In this respect, in the light of the product-quality literature (Ossa, 2015; Eaton and Kortum, 2002; Markusen, 2013), the effect of immigration can be considered by means of the output produced in the traded goods sector. Cross-industry variation in trade elasticity greatly magnifies the estimated gains from trade and imports in some industries and are critical to the functioning of the economy. Therefore, immigration gives rise to a gain that can be used to make the native population better off without excluding the immigrants from the redistribution scheme.

The final explanation lies in the assumption that the causal effect of immigration can be crucial for prices of non-traded goods and services. According to Cortés (2008), an increase in the share of low-skilled immigrants in the labour force decreases the price of immigrantintensive services, such as housekeeping and gardening. Comparatively, González and Ortega (2011) have found that regions that received a large inflow of unskilled immigrants increased the intensity to which more abundant unskilled labour was used, relative to other regions. The key industries responsible for this absorption were retail, construction, hotels and restaurants and domestic services. All of these industries produce non-traded goods.

Taken globally, in the process of technological change and restructuring there are reasons to ask how these are related to immigration and immigrants' contribution to restructuring. This research found that the contribution of ICT- and R\&D- capital input and intensity in particular has had a positive effect on the increase in incomes of all occupational groups both for immigrants and natives (especially for skilled and unskilled labour). In light of the evidence of Goos and Manning (2007), Bresnahan, Brynjolfsson and Hitt (2002), Goos, Manning and Salomons (2009), Michaels, Natraj and Van Reenen (2014), the impact of technology on low-skilled jobs is likely to lead to an upturn in employment in these occupations.

Another important finding and conclusion of this research is that the contribution of machinery and equipment on TFP seems to have a positive effect only for native skilled agricultural and fishery workers and plant and machine operators and assemblers. Based on the underlying assumption that routine and non-routine tasks are imperfect substitutes, within industries, occupations, and education groups, technological innovations are associated with 
reduced labour input for routine manual tasks and increased labour input for non-routine cognitive tasks. Therefore, manual labour for specific skilled occupations can hardly be replaced by technological innovations. Similarly, Brynjolfsson and Hitt (1998), Gordon (2012), Brynjolfsson and McAfee (2011), Brynjolfsson and McAfee (2014) and Bresnahan (2010) conclude that it is important to realize that technological innovations do not automatically increase productivity by themselves, but are an essential component of a broader system of organizational changes, which do increase productivity. This is not only important for firms but also for national economies, including Finland, which is experiencing alarming trends of decreasing productivity growth.

In general, it is important to emphasize that the political discussion about the role of immigrants in the economics is centred around the costs associated with income maintenance programs for immigrants as 'immigrant hordes', who have an adverse effect on the employment opportunities of natives. In this respect, the present research verified the hypothesis regarding the role of welfare state benefits in the income dynamics among immigrants as well as among natives. The research concludes that welfare state benefits (unemployment benefits, old-age benefits, survivor benefits, sickness benefits, disability benefits and education-related allowances) in combination with the influence from macro-economic regulators and productivity slightly increase the overall level of incomes for all occupational groups among immigrants. Similarly, Borjas and Trejo (1991), Baker and Benjamin (1995), Hansen and Lofstrom (2003) demonstrate higher participation rates in welfare state programs by immigrants than natives and that the probability of receiving welfare state benefits increases with the duration immigrants live in a country.

While numerous previous research aimed to estimate the effect from immigration upon increases or decreases in the value of aggregate output and the incomes of the native population, the present research aimed to estimate the effect from aggregate output, productivity and welfare state provision on the redistribution of incomes among immigrants and natives. In this respect, the present research fills a gap in understanding the reasons of poverty, job polarization and the factors (e.g., ITC and R\&D) which potentially would have an effect in increasing productivity and decreasing job polarization and wage differentials among immigrants and natives.

The multilevel modelling allowed investigation of the redistribution of incomes among immigrants and natives by means of two-step (micro-level and macro-level) analyses based on the random intercept/fixed slope model. When two levels of interaction have been considered in the same model, it is possible to consider how individual factors (education, occupation and industry) affect the redistribution of incomes due to the influence of macro-economic growth, productivity and welfare state provision, in addition to also enabling verification of argumentation concerning education-specific, occupation-specific and industry-specific labour markets in the polarization of incomes between immigrants and natives. This methodological advantage of multilevel modelling was crucial for the consideration and verification of macrolevel theoretical arguments. This method, however, provides even more advantages which have not been used in this research due to limited research questions.

In summary, the factors that drive research findings still need to be uncovered. Occupational downgrading among certain groups, institutional barriers to occupational practice or even discrimination may be promising areas for future research. While there are many empirical studies which focus on US and European countries, no analysis exists for Finland. Given the difference in migration history, settlement, and the type of immigration to Finland, it would be unwise to infer from other studies the possible effects of immigration on the labour market.

The debate over immigration policy has long been fuelled by the widespread perception that 'immigrant hordes' have an adverse effect on the employment opportunities of natives and 
their incomes. The choice of the 'right' immigration policy can obviously have a significant impact on the economic activity of immigrants both in the short and in the long run. The most important issue is that an assessment of the economic impact of immigration and the economic consequences of pursuing particular immigration policies requires an understanding of the factors which contribute to a more efficient economic performance of immigrants and more efficient productivity from immigrant labour. As a result, the most important lesson is that the economic impact of immigration will vary by time and place, and can be either beneficial or harmful.

\section{Acknowledgement}

The author is thankful to the Finnish Cultural Foundation (grant agreement \#01169473) for financial support to carry out this research.

\section{References}

Altonji, J. G., Card, D. (1991). "The Effect of Immigration on the Labor Market Outcomes of Less-Skilled Natives". In Abowd, J. M., Freeman, R. B. (Eds.). Immigration, Trade and the Labor Market. University of Chicago Press, Chicago.

Amuedo-Dorantes, C., \& De la Rica, S. (2011). Complements or Substitutes? Task Specialization by Gender and Nativity in Spain. Labour Economics, 18(5), 697-707. https://doi.org/10.1016/j.labeco.2011.02.002

Asplund, R., Barth, E., Lundborg, P., \& Nilsen, K. M. (2011). Polarization of the Nordic Labor Markets. Finnish Economic Papers, 24(2), 87-110.

Aydemir, A., \& Borjas, G. (2007). Cross-Country Variation in the Impact of International Migration: Canada, Mexico, and the United States. Journal of the European Economic Association, 5(4), 663-708. https://doi.org/10.1162/JEEA.2007.5.4.663

Aydemir, A., \& Borjas, G. (2011). Attenuation Bias in Measuring the Wage Impact of Immigration. Journal of Labor Economics, 29(1), 69-113. https://doi.org/10.1086/656360

Baker, M., \& Benjamin, D. (1995). The Receipt of Transfer Payments by Immigrants to Canada. The Journal of Human Resources, 30(4), 650-676. https://doi.org/10.2307/146226

Barth, E., Bernt, B. \& Raaum, O. (2004). Identifying the Earnings Assimilation of Immigrants under Changing Macroeconomic Conditions. Scandinavian Journal of Economics, 106(1), 1-22. https://doi.org/10.1111/j.0347-0520.2004.t01-1-00345.x

Barth, E., Bernt, B. \& Raaum, O. (2006). Local Unemployment and the Relative Wages of Immigrants: Evidence from the Current Population Surveys. Review of Economics and Statistics, 88(2), 243-263. https://doi.org/10.1162/rest.88.2.243

Bijwaard, G. E., \& Wahba, J. (2019). Immigrants' Wage Growth and Selective Out-Migration. Oxford Bulletin of Economics and Statistics, 81(5), 1065-1094. https://doi.org/10.1111/obes.12295

Bilan, Y., Mishchuk, H., Samoliuk, N., \& Grishnova, O. (2019). ICT and Economic Growth: Links and Possibilities of Engaging. Intellectual Economics, 13(1). https://doi.org/10.13165/IE-19-13-1-07

Blau, F.D., \& Kahn, L.M. (2012). Immigration and the Distribution of Incomes, Discussion Paper Series, Forschungsinstitut zur Zukunft der Arbeit, No.6921, 1-65. 
Blume, K., Gustafsson, B., Pedersen, P., \& Verner, M. (2007). At the Lower End of the Table - Determinants of Poverty among Immigrants to Denmark and Sweden. Journal of Ethnic and Migrant Studies, 33(3), 373-396. https://doi.org/10.1080/13691830701234517

Bonin, H. (2005). Wage and Employment Effects of Immigration to Germany: Evidence from a Skill Group Approach. IZA Discussion Paper No. 1875. 1-30.

Borjas, G. (1987). Immigrants, Minorities, and Labor Market Competition. Industrial and Labor Relations Review, 40(3), 382-392. https://doi.org/10.1177/001979398704000305

Borjas, G. J. (2003). The Labor Demand Curve Is Downward Sloping: Re-Examining The Impact of Immigration on The Labor Market. Quarterly Journal of Economics, 118(4), 1335-1374. https://doi.org/10.1162/003355303322552810

Borjas, G. J., Freeman, R. B., Katz, L.F. (1997). How Do Much Do Immigration and Trade Affect Labor Market Outcomes? Brookings Papers on Economic Activity, 1, 1-90. https://doi.org/10.2307/2534701

Borjas, G., \& Friedberg, R. (2009). Recent Trends in the Earnings of New Immigrants to the United States. NBER Working Paper, No. 15406(J6), 1-56.

Borjas, G., \& Hilton, L. (1996). Immigration and the Welfare State: Immigrant Participation in Means-Tested Entitlement Programs. Quarterly Journal of Economics, 111(2), 575-604. https://doi.org/10.2307/2946688

Borjas, G., \& Trejo, S. (1991). Immigrant Participation in the Welfare System. Industrial and Labor Relations Review, 44(2), 195-211. https://doi.org/10.1177/001979399104400201

Bresnahan, T. F. (2010). General Purpose Technologies. Handbook of the Economics of Innovation, 2, 761-791. https://doi.org/10.1016/S0169-7218(10)02002-2

Bresnahan, T. F., Brynjolfsson E. and Hitt L. M. (2002). Information Technology, Workplace Organization, and the Demand for Skilled Labor: Firm-Level Evidence. The Quarterly Journal of Economics, 117 (1), 339-376. https://doi.org/10.1162/003355302753399526

Bresnahan, T.F. (1999). Computerisation and Wage Dispersion: An Analytical Reinterpretation. The Economic Journal, $109 \quad$ (456), 390-415. https://doi.org/10.1111/1468-0297.00442

Brynjolfsson, E., \& Hitt, L. M. (1998). Beyond The Productivity Paradox. Communications of the ACM, 41(8), 49-55. https://doi.org/10.1145/280324.280332

Brynjolfsson, E., \& McAfee, A. (2011). Race against the Machine. Lexington, MA: Digital Frontier Press.

Brynjolfsson, E., \& McAfee, A. (2014). The Second Machine Age: Work, Progress, and Prosperity in a Time of Brilliant Technologies. New York, NY: WW Norton and Company.

Card, D. (1990). The Impact of the Mariel Boatlift on the Miami Labor Market. Industrial \& Labor Relations Review, 43(2), 245-257. https://doi.org/10.1177/001979399004300205

Card, D. (2001). Immigrant Inflows, Native Outflows, and the Local Labor Market Impacts of Higher Immigration. Journal of Labor Economics, 19(1), 22-64. https://doi.org/10.1086/209979

Card, D. (2005). Is the New Immigration Really So Bad? The Economic Journal, 115(507), F300-F323. https://doi.org/10.1111/j.1468-0297.2005.01037.x

Card, D. (2009). Immigration and Inequality. American Economic Review, 99(2), 1-21. https://doi.org/10.1257/aer.99.2.1

Card, D., \& Lemieux, T. (2001). Can Falling Supply Explain The Rising Return To College For Younger Men? A Cohort-Based Analysis. Quarterly Journal of Economics, 116(2), 705-746. https://doi.org/10.1162/00335530151144140

Chiswick, B.R. (1978). The Effect of Americanization on the Earnings of Foreign-Born Men. Journal of Political Economy, 86(5), 897-921. https://doi.org/10.1086/260717 
Clarke, A., Ferrer, A., \& Skuterud, M. (2019). A Comparative Analysis of the Labor Market Performance of University-Educated Immigrants in Australia, Canada, and the United States: Does Policy Matter?. Journal of Labor Economics, 37(S2), 443-490. https://doi.org/10.1086/703256

Cohen-Goldner, S., \& Paserman, M. D. (2011). The Dynamic Impact of Immigration on Natives' Labor Market Outcomes: Evidence from Israel. European Economic Review, 55, 1027-1045. https://doi.org/10.1016/j.euroecorev.2011.05.002

Cortés, P. (2008). The Effect of Low-Skilled Immigration on U.S. Prices: Evidence from CPI Data. Journal of Political Economy, 116(3), 381-422. https://doi.org/10.1086/589756

D'Amuri, F., Ottaviano, G. I. P., Peri, G. (2010). The Labor Market Impact of Immigration in Western Germany. European Economic Review, 54, 550-570. https://doi.org/10.1016/j.euroecorev.2009.10.002

Dustmann, C., Fabbri, F., Preson, I. (2005). The Impact of Immigration on the British Labour Market. The Economic Journal, 115(507), F324-F341. https://doi.org/10.1111/j.14680297.2005.01038.x

Dustmann, C., Frattini, T., Preston, I. (2013). The Effect of Immigration along the Distribution of Wages. The Review of Economic Studies, 80(1), 145-173. https://doi.org/10.1093/restud/rds019

Eaton, J., \& Kortum, S. (2002). Technology, Geography, and Trade. Econometrica, 70(5), 1741-1779. https://doi.org/10.1111/1468-0262.00352

Felbermayra, G., Hiller, S., \& Sala, D. (2010). Does Immigration Boost Per Capita Income? Economics Letters, 107(2), 177-179. https://doi.org/10.1016/j.econlet.2010.01.017

Friedberg, R. M. (2001). The Impact of Mass Migration on the Israeli Labor Market. Quarterly Journal of Economics, 116(4), 1373-1408. https://doi.org/10.1162/003355301753265606

Galloway, T., \& Aaberge, R. (2005). Assimilation Effects on Poverty among Immigrants to Norway. Journal of Population Economics, 18(4), 691-718. https://doi.org/10.1007/s00148-005-0002-6

Galloway, T.A. (2008). Re-Examining the Earnings Assimilation of Immigrants. Discussion Papers No. 570, 1-43.

González, L., Ortega, F. (2011). How Do Very Open Economies Absorb Large Immigration Flows? Recent Evidence from Spanish Regions. Labour Economics, 18, 57-70. https://doi.org/10.1016/j.labeco.2010.06.001

Goos, M., and Manning, A. (2007). Lousy and Lovely Jobs: The Rising Polarization of Work in Britain. The review of economics and statistics, 89(1), 118-133. https://doi.org/10.1162/rest.89.1.118

Goos, M., Manning, A., and Salomons, A. (2009). Job Polarization in Europe. The American Economic Review, 58-63. https://doi.org/10.1257/aer.99.2.58

Gordon, R. J. (2012). Is US Economic Growth Over? Faltering Innovation Confronts The Six Headwinds (No. w18315). National Bureau of Economic Research. https://doi.org/10.3386/w18315

Gustafsson, B., \& Zheng, J. (2006). Earnings of Immigrants in Sweden 1978-1999. International Migration, 44(2), 79-117. https://doi.org/10.1111/j.14682435.2006.00365.x

Hammarstedt, M. (2003). Income from Work among Immigrants in Sweden. Review of Income and Wealth, 49(2), 185-203. https://doi.org/10.1111/1475-4991.00082

Hansen, J., \& Lofstrom, M. (2003). Immigrant Assimilation And Welfare Participation: Do Immigrants Integrate Into Or Out Of Welfare? Journal of Human Resources, 38(1), 7498. https://doi.org/10.2307/1558756

Lewis, E. (2003). Local Open Economics Within The U.S.: How Do Industries Respond To Immigration? Federal Reserve Bank of Philadelphia Working Paper No. 04-1. 
Lewis, J., \& Linzer, D. (2005). Estimating Regression Models In Which The Dependent Variable Is Based On Estimates. Political Analysis, 13(4), 345-364. https://doi.org/10.1093/pan/mpi026

Manacorda, M., Manning, A., Wadsworth, J. (2012). The Impact of Immigration on the Structure of Male Wages: Theory and Evidence for Britain. Journal of the European Economic Association, 10(1), 120-151. https://doi.org/10.1111/j.15424774.2011.01049.x

Markusen, J.R. (2013). Putting Per-Capita Income Back Into Trade Theory. Journal of International Economics, 90(2), 255-265. https://doi.org/10.1016/j.jinteco.2013.04.003

Martins, P., Piracha, M., \& Varejão, J. (2018). Do Immigrants Displace Native Workers? Evidence from Matched Panel Data. Economic Modelling, 72, 216-222. https://doi.org/10.1016/j.econmod.2018.01.019

Michaels, G., Natraj, A., and Van Reenen, J. (2014). Has ICT Polarized Skill Demand? Evidence from Eleven Countries Over Twenty-Five Years. Review of Economics and Statistics, 96(1), 60-77. https://doi.org/10.1162/REST_a_00366

Mishchuk, H., Roshchyk, I., Sułkowska, J. \& Vojtovič, S. (2019). Prospects of Assessing the Impact of External Student Migration on Restoring the Country's Intellectual Potential (Case Study of Ukraine). Economics \& Sociology, 12(3), 209-219. https://doi.org/10.14254/2071-789X.2019/12-3/14

Mitrunen, M. (2013). Työmarkkinoiden polarisaatio Suomessa. (Labour Market Polarization in Finland). Government Institute for Economic Research, VATT Mimeo, 33.

Noguer, M., \& Siscart, M. (2005). Trade Raises Income: A Precise and Robust Result. Journal of International Economics, 65(2), 447-460. https://doi.org/10.1016/j.jinteco.2003.11.006

Ortega, F., Peri, G. (2014). Openness and Income: The Roles of Trade and Migration. Journal of International Economics, 231-251. https://doi.org/10.1016/j.jinteco.2013.11.008

Ossa, R. (2015). Why Trade Matters After All? Journal of International Economics, 97(2), 266277. https://doi.org/10.1016/j.jinteco.2015.07.002

Ottaviano, G., \& Peri, G. (2008). Immigration and National Wages: Clarifying the Theory and the Empirics. National Bureau of Economic Research Working Papers, \#14188, Cambridge, MA. https://doi.org/10.3386/w14188

Ottaviano, G.I.P., \& Peri, G. (2012). Rethinking the Effect of Immigration on Wages. Journal of the European Economic Association, 10, 152-197. https://doi.org/10.1111/j.15424774.2011.01052.x

Peri, G., \& Sparber, C. (2009). Task Specialization, Immigration, and Wages. American Economic Journal: Applied Economics, 1(3), 135--169. https://doi.org/10.1257/app.1.3.135

Rodrik, D., Subramanian A., \& Trebbi F. (2004). Institutions Rule: The Primacy of Institutions over Geography and Integration in Economic Development. Journal of Economic Growth, 9(2), 271-293. https://doi.org/10.1023/B:JOEG.0000031425.72248.85

Villarreal, A., \& Tamborini, C. R. (2018). Immigrants' Economic Assimilation: Evidence from Longitudinal Earnings Records. American Sociological Review, 83(4), 686-715. https://doi.org/10.1177/0003122418780366

Winter-Ebmer, R., \& Zweimüller, J. (1996). Immigration and the Earnings of Young Native Workers. Oxford Economic Papers, 48(3), 473-491. https://doi.org/10.1093/oxfordjournals.oep.a028579 


\section{Appendix}

Table 1. Summary statistics for cash income and social benefits (EU-SILC)

\begin{tabular}{|c|c|c|c|c|c|c|c|c|c|c|}
\hline & \multicolumn{5}{|c|}{ Immigrants } & \multicolumn{5}{|c|}{ Natives } \\
\hline & Obs & Min & Max & Mean & Std.dev. & Obs & Min & Max & Mean & Std.dev. \\
\hline Cash income & 2484 & 0 & 171843 & 26302,67 & 21567,96 & 107501 & 0 & 683803 & 28585,67 & 26335,6 \\
\hline $\begin{array}{l}\text { Unemployment } \\
\text { benefits }\end{array}$ & 2484 & 0 & 20260 & 864,81 & 2324,35 & 107501 & 0 & 46309 & 367,79 & 1642,85 \\
\hline $\begin{array}{l}\text { Old-age } \\
\text { benefits }\end{array}$ & 2484 & 0 & 46512 & 84,86 & 1359,22 & 107501 & 0 & 137533 & 414,48 & 3206,21 \\
\hline $\begin{array}{l}\text { Survivor' } \\
\text { benefits }\end{array}$ & 2484 & 0 & 10284 & 20,41 & 426,72 & 107501 & 0 & 83797 & 56,18 & 801,32 \\
\hline $\begin{array}{l}\text { Sickness } \\
\text { benefits }\end{array}$ & 2484 & 0 & 10615 & 80,99 & 549,09 & 107501 & 0 & 40313 & 125,64 & 884,81 \\
\hline $\begin{array}{l}\text { Disability } \\
\text { benefits }\end{array}$ & 2484 & 0 & 18570 & 114,30 & 995,87 & 107501 & 0 & 75431 & 221,00 & 1664,54 \\
\hline $\begin{array}{l}\text { Education- } \\
\text { related } \\
\text { allowances }\end{array}$ & 2484 & 0 & 27755 & 128,53 & 1076,37 & 107501 & 0 & 74750 & 98,95 & 891,36 \\
\hline
\end{tabular}

Source: own calculations are based on the European Union Statistics on Income and Living Conditions (EU-SILC) cross-sectional micro-data for Finland for the period of 2004 to 2016 (a sample of 2,484 cases for immigrants and 107,501 cases for natives)

Table 2. Descriptive statistics on basic categorical variables, used in the analysis

\begin{tabular}{|c|c|c|c|c|}
\hline & \multicolumn{2}{|c|}{ Immigrants } & \multicolumn{2}{|c|}{ Natives } \\
\hline & Freq. & Percent & Freq. & Percent \\
\hline \multicolumn{5}{|l|}{ Education } \\
\hline Higher education & 1196 & 48,15 & 45402 & 42,23 \\
\hline Low and medium education & 1288 & 51,85 & 62099 & 57,77 \\
\hline Total & 2484 & 100 & 107501 & 100 \\
\hline \multicolumn{5}{|l|}{ Occupation } \\
\hline Legislators, senior officials and managers & 144 & 5,80 & 11118 & 10,34 \\
\hline Professionals & 618 & 24,88 & 22377 & 20,82 \\
\hline Technicians and associate professionals & 342 & 13,77 & 16822 & 15,65 \\
\hline Clerks & 106 & 4,27 & 6120 & 5,69 \\
\hline Service workers and shop and market sales workers & 547 & 22,02 & 17542 & 16,32 \\
\hline Skilled agricultural and fishery workers & 67 & 2,70 & 9490 & 8,83 \\
\hline Craft and related trades workers & 265 & 10,67 & 11259 & 10,47 \\
\hline Plant and machine operators and assemblers & 161 & 6,48 & 7679 & 7,14 \\
\hline Elementary occupations & 234 & 9,42 & 5094 & 4,74 \\
\hline Total & 2484 & 100 & 107501 & 100 \\
\hline \multicolumn{5}{|l|}{ Industry } \\
\hline Financial intermediation & 20 & 0,81 & 2337 & 2,17 \\
\hline Agriculture, hunting and forestry, fishing & 66 & 2,66 & 10276 & 9,56 \\
\hline $\begin{array}{l}\text { Mining and quarrying, manufacturing, electricity, } \\
\text { gas and water supply }\end{array}$ & 330 & 13,29 & 16097 & 14,97 \\
\hline Construction & 134 & 5,39 & 7939 & 7,39 \\
\hline $\begin{array}{l}\text { Wholesale and retail trade; repair of motor vehicles, } \\
\text { motorcycles and personal and household goods }\end{array}$ & 318 & 12,80 & 12162 & 11,31 \\
\hline Hotels and restaurants & 180 & 7,25 & 2753 & 2,56 \\
\hline Transport, storage and communication & 221 & 8,90 & 10481 & 9,75 \\
\hline Real estate, renting and business activities & 260 & 10,47 & 11022 & 10,25 \\
\hline $\begin{array}{l}\text { Public administration and defence, compulsory } \\
\text { social security }\end{array}$ & 66 & 2,66 & 5007 & 4,66 \\
\hline Education & 237 & 9,54 & 7464 & 6,94 \\
\hline Health and social work & 484 & 19,48 & 16252 & 15,12 \\
\hline $\begin{array}{l}\text { Other community, social and personal service } \\
\text { activities, private households with employed } \\
\text { persons, extra-territorial organisations and bodies }\end{array}$ & 168 & 6,76 & 5711 & 5,31 \\
\hline Total & 2484 & 100 & 107501 & 100 \\
\hline
\end{tabular}


Source: own calculations are based on the European Union Statistics on Income and Living Conditions (EU-SILC) cross-sectional micro-data for Finland for the period of 2004 to 2016 (a sample of 2,484 cases for immigrants and 107,501 cases for natives)

Table 3. Summary statistics for macro-economic indicators (Statistics of Finland) used in the analysis

\begin{tabular}{|c|c|c|c|c|c|c|c|c|c|c|c|c|c|c|}
\hline \multirow[t]{2}{*}{ Year } & \multirow{2}{*}{$\begin{array}{c}\text { Gross } \\
\text { domest } \\
\text { ic } \\
\text { produc } \\
\text { t, } \\
\text { change } \\
\text { in } \\
\text { values }\end{array}$} & \multirow{2}{*}{$\begin{array}{c}\text { Gross } \\
\text { nation } \\
\text { al } \\
\text { income } \\
, \\
\text { change } \\
\text { in } \\
\text { values }\end{array}$} & \multirow{2}{*}{$\begin{array}{c}\text { Value } \\
\text { added } \\
\text { change } \\
, \%\end{array}$} & \multirow{2}{*}{$\begin{array}{c}\text { Labou } \\
\quad r \\
\text { produc } \\
\text { tivity, } \\
\text { change } \\
, \%\end{array}$} & \multirow{2}{*}{$\begin{array}{c}\text { Multi- } \\
\text { factor } \\
\text { produc } \\
\text { tivity, } \\
\text { change } \\
, \%\end{array}$} & \multicolumn{5}{|c|}{$\begin{array}{c}\text { Total-factor productivity, contribution } \\
\text { in value added: }\end{array}$} & \multicolumn{4}{|c|}{$\begin{array}{l}\text { Labour productivity, contribution in } \\
\text { value added: }\end{array}$} \\
\hline & & & & & & $\begin{array}{c}\text { Total } \\
\text { capita } \\
1 \\
\text { input, } \\
\%\end{array}$ & $\begin{array}{c}\text { ICT- } \\
\text { capita } \\
1 \\
\text { input, } \\
\%\end{array}$ & $\underset{\%}{\text { R\&D, }}$ & $\begin{array}{c}\text { Machi } \\
\text { nery } \\
\text { and } \\
\text { equip } \\
\text { ment, } \\
\%\end{array}$ & $\begin{array}{c}\begin{array}{c}\text { Work } \\
\text { ed } \\
\text { hours, } \\
\%\end{array} \\
\text { \% }\end{array}$ & $\begin{array}{c}\text { Capital } \\
\text { intensit } \\
\mathbf{y}, \%\end{array}$ & $\begin{array}{c}\text { ICT- } \\
\text { capital } \\
\text { intensit } \\
\mathbf{y}, \%\end{array}$ & $\begin{array}{c}\text { R\&D } \\
\text { intensit } \\
\mathbf{y}, \%\end{array}$ & $\begin{array}{c}\text { Equipm } \\
\text { ent and } \\
\text { machin } \\
\text { ery } \\
\text { capital } \\
\text { intensit } \\
y, \%\end{array}$ \\
\hline 2004 & 4.6 & 5.9 & 3.813 & 3.3 & 2.602 & 0.806 & 0.244 & 0.312 & -0.055 & 0.405 & 0.698 & 0.242 & 0.296 & -0.054 \\
\hline 2005 & 3.7 & 3.4 & 2.49 & 1.586 & 1.025 & 0.897 & 0.287 & 0.221 & 0.046 & 0.568 & 0.56 & 0.286 & 0.096 & 0.174 \\
\hline 2006 & 5 & 5.6 & 3.792 & 2.27 & 1.978 & 0.754 & 0.24 & 0.171 & -0.003 & 1.06 & 0.292 & 0.183 & 0.204 & -0.164 \\
\hline 2007 & 8.1 & 7.4 & 5.664 & 3.898 & 3.207 & 1.2 & 0.348 & 0.265 & 0.16 & 1.257 & 0.69 & 0.317 & 0.224 & 0.081 \\
\hline 2008 & 3.8 & 3.7 & 0.801 & -0.461 & -1.558 & 1.205 & 0.273 & 0.35 & 0.156 & 1.154 & 1.097 & 0.25 & 0.481 & 0.1 \\
\hline 2009 & -6.5 & -5.5 & -9.198 & -5.069 & -6.785 & 0.493 & 0.112 & 0.083 & 0.016 & -2.905 & 1.716 & 0.295 & 0.665 & 0.518 \\
\hline 2010 & 3.4 & 3.4 & 3.015 & 3.243 & 2.807 & 0.334 & 0.075 & 0.068 & -0.112 & -0.126 & 0.436 & 0.101 & 0.228 & -0.111 \\
\hline 2011 & 5.2 & 4.3 & 1.925 & 1.334 & 0.822 & 0.41 & 0.083 & -0.003 & -0.058 & 0.694 & 0.512 & 0.075 & 0.068 & -0.112 \\
\hline 2012 & 1.5 & 1.6 & -2.037 & -2.014 & -2.519 & 0.487 & 0.089 & 0.026 & 0.051 & -0.005 & 0.505 & 0.105 & 0.019 & 0.082 \\
\hline 2013 & 1.8 & 1.6 & -1.11 & 0.433 & -0.323 & 0.248 & 0.066 & -0.024 & -0.06 & -1.035 & 0.756 & 0.11 & 0.088 & 0.037 \\
\hline 2014 & 1.1 & 1.6 & -0.62 & 0.488 & -0.369 & 0.316 & 0.104 & -0.067 & -0.044 & -0.566 & 0.857 & 0.158 & 0.072 & 0.048 \\
\hline 2015 & 2 & 2 & -0.047 & -0.225 & -0.214 & 0.27 & 0.116 & -0.105 & -0.03 & -0.103 & -0.01 & 0.138 & -0.038 & 0.051 \\
\hline 2016 & 3.1 & 3.6 & 1.576 & 1.229 & 0.893 & 0.372 & 0.069 & -0.091 & 0.05 & 0.311 & 0.336 & 0.065 & -0.026 & 0.059 \\
\hline Min & -6.500 & -5.500 & -9.198 & -5.069 & -6.785 & 0.248 & 0.066 & -0.105 & -0.112 & -2.905 & -0.010 & 0.065 & -0.038 & -0.164 \\
\hline Max & 8.100 & 7.400 & 5.664 & 3.898 & 3.207 & 1.205 & 0.348 & 0.350 & 0.160 & 1.257 & 1.716 & 0.317 & 0.665 & 0.518 \\
\hline Mean & 2.878 & 3.025 & 0.853 & 0.830 & 0.183 & 0.605 & 0.164 & 0.096 & 0.008 & 0.065 & 0.647 & 0.180 & 0.183 & 0.053 \\
\hline $\begin{array}{l}\text { Std.de } \\
\text { v. }\end{array}$ & 3.189 & 2.955 & 3.524 & 2.301 & 2.543 & 0.327 & 0.096 & 0.150 & 0.079 & 1.056 & 0.399 & 0.085 & 0.192 & 0.160 \\
\hline
\end{tabular}

